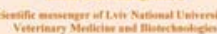
15 10 ingme 4 in the mis

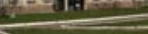

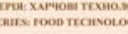
Том 21 Nis 91 2019
Науковий вісник Аьвівського національного університету ветеринарної медицини та біотехнологій імені С.3. Гжицького. Серія: Харчові технології

\author{
Scientific Messenger of Lviv National University
} of Veterinary Medicine and Biotechnologies.

Series: Food Technologies

ISSN 2519-268X print

https://nvlvet.com.ua/index.php/food

UDC 663.834

\title{
The rheological properties of cream liqueurs and their changes in the transportation process
}

T.V. Bozhko, R.S. Donchevska, R.P. Romanenko

Kyiv National University of Trade and Economics, Kyiv, Ukraine

Article info

Received 11.02.2019

Received in revised form 11.03.2019

Accepted 12.03.2019

Kyiv National University of Trade and Economics, Kyoto str., 19 , Kyiv-156, 02156, Ukraine Tel.: +38-097-543-76-30 E-mail: tatyanabozhko@ukr.net
Bozhko, T.V., Donchevska, R.S., \& Romanenko, R.P. (2019). The rheological properties of cream liqueurs and their changes in the transportation process. Scientific Messenger of Lviv National University of Veterinary Medicine and Biotechnologies. Series: Food Technologies, 21(91), 149_ 156. doi: $10.32718 /$ nvlvet-f9125

In order to determine the stability of colloidal systems of cream liqueurs with cycloractate and egg yolks, their rheological properties after production and during transportation, which was simulated through centrifugation and shaking, study, had been studied. Kinematic viscosity was determined by viscosimetric method using a graduated glass unit and a "Universal Computer Measuring Instrument" manufactured by "ITM Ltd.", Kharkiv, Ukraine. The coefficient of surface tension was investigated by the method of detachment of the ring from the surface of the test substance, and the density - by the method of hydrostatic weighing. Storage of bottled glass bottles with a capacity of 0.35 l of dessert emulsion cream liqueurs took place in the warehouse at a temperature from +10 to $+250 \mathrm{C}$ and a relative humidity of no more than $85 \%$. Quality indicators in developed beverages were determined at 18, 36, 54, 72, 90 and 108 day. Dynamic viscosity of the sample of dessert emulsion cream liqueur "Healing Source" was $2394.1 \mathrm{MPa} \cdot \mathrm{s}$, cream liqueur "Health" - 2219.7 MPa • s, control sample "Dalkowski Advocaat Starotoruński" - 1949.99 MPa • s. It has been established that the kinematic viscosity and density of developed cream liqueurs are higher by 19.4 ... 21.8\% compared with the control sample. For cocktails preparation it is expedient to use a dessert emulsion cream liqueur "Healing Source", the difference of the coefficient of surface tension of which with the control sample lies within the limits of statistical error it is determined. It is noted that in the process of centrifugation, cream liqueurs demonstrate a slight change in rheological properties. The smallest changes in density are noted for emulsion cream liqueur "Healing Source», the largest - for "Health", due to the peculiarities of their prescription composition. The influence of "shaking effect" on the density of dessert emulsion cream liqueurs was determined. The biggest difference in density after shaking up to $10 \mathrm{~s}$ had the cream-liqueur "Health", after 10s of shaking - the cream-liqueur "Steppe beauty". The most stable structure of the colloidal system of the cream-liqueur "Healing Source" was the stability difference with the control sample lies within the statistical error.

Key words: cream liqueurs, rheological properties, kinematic viscosity, dynamic viscosity, density, centrifugation, transportation.

\section{Реологічні властивості крем-лікерів та їх зміни в процесі транспортування}

\author{
Т.В. Божко, Р.С. Дончевська, Р.П. Романенко
}

Київський національний торговельно-економічний університет, м. Київ, Украӥна

3 метою визначення стійкості колоїдних систем крем-лікерів з иикорлактом та яєчними жовтками у було проведено дослідження їх реологічних властивостей після виробництва та під час транспортування, моделювання якого здійснювали шляхом иентрифугування та струшування. Кінематичну в 'язкість визначали візкозиметричним методом із використанням градуйованої скляної установки та “Універсального комп'ютерного вимірювального приладу” виробництва ТОВ “ІТМ”, м. Харків, Україна. Коефіцієнт поверхневого натягу досліджували методом відриву кільия від поверхні досліджуваної речовини, густину - методом гідростатичного зважування. Зберігання розлитих у скляні пляшки ємністю 0,35 л десертних емульсійних крем-лікерів відбувалось у складському приміщенні при температурі від +10 до $+25{ }^{\circ} \mathrm{C}$ та відносній вологості не більще 85\%. Показники якості в розробле- 
них напоях визначалися на 18, 36, 54, 72, 90 та 108 добу. Динамічна в'язкість зразка десертного емульсійного крем-лікеру “Цілюще джерело” становила 2394,1 МПа·с, крем-лікеру “Здоров'я” - 2219,7 MПа.c, контрольного зразка “Dalkowski Advocaаt Starotoruński” - 1949,99 МПа·c. Встановлено, щчо кінематична в'язкість та густина розроблених крем-лікерів є вищими на $19,4 \ldots 21,8 \%$ порівняно з контрольним зразком. Визначено, щзо для приготування коктейлів дочільно застосовувати десертний емульсійний крем-лікер “Цілюще джерело”, різниця коефіцієнту поверхневого натягу якого з контрольним зразком лежить у межах статистичної похибки. Відмічено, щуо в прочесі иентрифугування крем-лікери демонструють незначну зміну реологічних властивостей. Найменші зміни густини відмічено для емульсійного крем-лікеру “Цілюще джерело”, найбільші - для “Здоров'я”, щзо пов'язано з особливостями їх рецептурного складу. Визначено вплив “ефекту струшування” на густину десертних емульсійних крем-лікерів. Найбільша різниия густини після струшування до 10с - у крем-лікеру “Здоровя”, після 10с струшування - у кремлікеру “Степова красуня”. Найбільш стабільною виявилася структура колоїдної системи крем-лікеру “Цілюще джерело” різниця стабільності якої з контрольним зразком лежить у межах статистичної похибки.

Ключові слова: крем-лікери, реологічні властивості, кінематична в 'язкість, динамічна в'язкість, густина, иентрифугування, транспортування.

\section{Вступ}

Формування культури споживання алкогольвмісних продуктів $\epsilon$ важливою складовою збереження здоров'я нації. Адже надмірне споживанняміцних алкогольних напоїв $\epsilon$ соціально-етичною проблемою багатьох країн світу (Hahn et al., 2012). У зв’язку з цим, альтернативою міцним напоям є напої з невисоким відсотком етилового спирту та корисними біологічно цінними інгредієнтами при споживанні в невеликих дозах крем-лікери (Cobley, 1994; Lovchev, 2013; Savchuk et al., 2016).

Крем-лікери - продукція, в якій мінімальна концентрація спирту в об'ємному відсотку складає 15\% (згідно з класифікацією за Регламентом № 110/2008 Європейського парламенту і Ради ЄC) (Rehlament Yevropeiskoho parlamentu i rady IeS). До їх складу входять яєчні жовтки, цукор та коньяк, а з метою подовження термінів зберігання, поліпшення смакоароматичних властивостей, стабілізації емульсії готових продуктів додаються численні штучні харчові добавки - консерванти, емульгатори, стабілізатори тощо (Регламент № 1333/2008 Свропейського парламенту і Ради СC) (Reglament ES).

Проте, основною проблемою формування споживних властивостей крем-лікерів є складність забезпечення стабільності емульсії при зберіганні без використання штучних добавок. В той же час, в Україні існують натуральні компоненти, які можуть бути включені до рецептур крем-лікерів з метою формування стійкої колоїдної системи у процесі транспортування (Rudavska \& Holub, 1999; Holub, 2006). Відповідно, з метою вирішення даної проблеми було розроблено рецептури крем-лікерів спиртовій основі та на основі бальзаму “Цілющий” з цикорлактом та яєчними жовтками.

Структурно-механічні (реологічні) властивостіхарчових продуктів $є$ одними із важливих властивостей колоїдних систем, на яківпливають природа дисперсної фази і дисперсійного середовища, присутність у системі стабілізатора (Jarvis et al., 2005). Саме від цих факторів значною мірою залежить інтенсивність сил міжмолекулярної взаємодії: ці сили діють як між частинками дисперсної фази, так і між частинками дисперсної фази і молекулами розчинника (Hrebelnyk et al., 2016). Структура колоїдної системи надає їй певних реологічних властивостей. Емульсійні кремилікериє вільно дисперсними системами, які виявляють тенденцію до в'язкої течії,тобто до безупинної зміни своєї форми 3 часом навіть за наявності потужних зсувних деформацій (Buffle \& Leppard, 1995).

Структури в колоїдних системах поділяються на коагуляційні (тиксотропно-оборотні) та конденсаційно-кристалізаційні (необоротно-зруйновані). У коагуляційних структурах, до яких належать емульсійні креми-лікери,частинки пов'язані між собою молекулярними силами зчеплення i утворюють суцільну сітку або каркас (Philipse \& Wierenga, 1998). Міцність каркаса залежить від наявності сольватного (гідратного) шару на поверхні частинок (Ansell \& Dickinson, 1985). Відмінними ознаками таких структур є: порівняно невелика міцність зв'язку між частинками; здатність до мимовільного відновленню структури після руйнування; пружність, пластичність, в'язкість. При зневодненні міцність таких структур підвищується, і після певної межі, вони перестають відновлюватись (Israelachvili \& Wennerström, 1996). Відповідно, дослідження динаміки реологічних властивостей емульсійних кремів-лікерів в процесі транспортування $\epsilon$ актуальним завданням.

Аналізом сучасних наукових і патентних джерел встановлено відсутність досліджень реологічних властивостей десертних емульсійних крем-лікерів залежно від рецептурного складу та впливу товароруху. Проте, значний внесок у формування споживних властивостей алкогольних напоїв 3 використанням натуральної рослинної сировини внесли такі вітчизняні та закордонні науковці, як: Домарецький В., Порохняк-Гановська Л., Руднєв М., Кисла Л., Попова В., Ляшенко В., Махина Л., Макаров П., Бурмістров Г., Муліна Н., Кримкова В., Лєвін Б., Рахімова M., Дюркан E., A.Lynch, D.Milvihill та ін. (Lynch \& Milvihill, 1997; Porokhniak-Hanovska et al., 2002; Djurkan, 2002; Marynchenko et al., 2003; Rahimova et al., 2014).

Мета роботи - дослідження реологічних властивостей десертних емульсійних крем-лікерів залежно від впливу сировинних компонентів та їх змін у процесі транспортування.

\section{Матеріал та методи досліджень}

Об'єкти досліджень - десертні емульсійні кремлікери: “Степова красуня" - на спиртовій основі 3 цикорлактом та яєчними жовтками; “Цілюще джерело" - на основі бальзаму "Цілющий” з цикорлактом та яєчними жовтками; “Здоров'я” - на спиртовій основі 3 цикорлактом та соєвим фітолецитином, а 
також та яєчний лікер "Dalkowski Advocaat Starotoruński" (виробник "Vinpol", Польща) в якості контролю.

Предмет досліджень - реологічні властивості десертних емульсійних крем-лікерів та яєчного лікеру після виробництва та впродовж транспортування.

Реологічні властивостідесертних емульсійних крем-лікерів досліджували за такими показниками, якабсолютна (динамічна) в'язкість, коефіцієнт поверхневого натягу,кінематична в'язкість, густина.

Кінематичну в'язкість визначали візкозиметричним методом із використанням градуйованої скляної установки, “Універсального комп'ютерного вимірювального приладу”, цифрових динамометрів і програмного забезпечення “Лабораторія ІТМ” при $\mathrm{t}=23{ }^{\circ} \mathrm{C}$ згідно з методикою, розробленою на кафедрі інженерно-технічних дисциплін КНТЕУ за формулою:

$$
v=K v_{\text {роз }}\left(\frac{\pi d_{1} t_{3 p}}{2 l_{1} t_{p о 3}}-\frac{\pi d_{2} t_{3 p}}{4 l_{2} t_{p о 3}}\right),
$$

$$
\begin{aligned}
& \text { де } t_{3 p}-\text { час повного витікання зразка через } \\
& K=\frac{2 R}{d_{1}-d_{2}}, \\
& K=\cos \varphi_{p},
\end{aligned}
$$

де $R$ - радіус перерізу переходу між циліндрами;

$\varphi_{p} \quad-\quad$ кут площини переходу між циліндрами до стінок циліндра більшого діаметру.

Для характеристики рідких продуктів харчування частіше використовують термін “абсолютна в'язкість”. Переведення кінематичної в'язкості десертних емульсійних крем-лікерів в абсолютну або, як частіше називають, динамічну, проводили за формулою:

$$
\delta_{\partial}=v \cdot \rho
$$

$$
\begin{aligned}
& \text { де } \delta_{\partial} \quad-\text { абсолютна (динамічна) в'язкість; }
\end{aligned}
$$

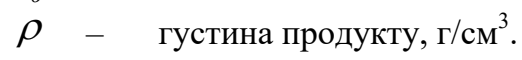

Коефіцієнт поверхневого натягу досліджували методом відриву кільця від поверхні досліджуваної речовини 3 використанням "Універсального комп'ютерного вимірювального приладу” з підвішеним гаком, штангенциркуля і програмного забезпечення "Лабораторія ITM" при $\mathrm{t}=20{ }^{\circ} \mathrm{C}$ (Shapoval et al., 2017), за формулою:

$$
\sigma=\frac{F_{1}-P}{\pi\left(d_{1}+d_{2}\right)},
$$

де $\sigma$ - коефіцієнт поверхневого натягу;

$F \quad$ - сила відриву від поверхні рідини, $\mathrm{H}$;

$P \quad$ - сила ваги кільця, $\mathrm{H}$;

$\pi \quad$ - математична стала, що дорівнює 3,14;

$d_{l} \quad$ - зовнішній діаметр кільця, мм;

$d_{2} \quad$ - внутрішній діаметр кільця, мм.

Дослідження реологічних властивостей десертних емульсійних крем-лікерів в процесі зберігання проводили з періодичністю, яку визначали з урахуванням передбаченого строку придатності та специфіки продукту, але не менше 5 разів з врахуванням передбачуваного строку придатності до 90 діб. Так, показники якості в розроблених напоях визначалися на 18,36 , 54, 72, 90 та 108 добу.

Зберігання розлитих у скляні пляшки за ДСТУ ГОСТ 10117.1-2003 (DSTU HOST 10117.1-2003) ємністю 0,35 л десертних емульсійних крем-лікерів відбувалось у складському приміщенні при температурі від +10 до $+25{ }^{\circ} \mathrm{C}$ та відносній вологості не більше $85 \%$. Зберігання напоїв здійснювалось на відстані від вікон для запобігання потраплянню на них прямих сонячних променів.

3 метою моделювання процесів розшарування емульсії при транспортуванні, зберіганні, а також використанні у складі коктейлів розроблених десертних емульсійних крем-лікерів нами були додатково проведені дослідження їх густини методом гідростатичного зважування.

Для реалізації методу нами була виготовлена спеціальна кругла гиря із дюралюмінію діаметром 8 мм і висотою 15 мм. Верхня частина цієї гирі звужена, де на відстані 2 мм від краю зроблено отвір діаметром 2 мм для закріплення підвісу. Підвіс виконано із сталевого дроту діаметром 0,15 мм і довжиною 50 мм, один кінець якого закріплено в отворі гирі, а інший у формі гачка причіплявся до коромисла аналітичних терезів. Нами використані терези, які оснащено шкалою 3 ціною поділки 3 мг. Таким чином, масу гирі можна було визначати 3 точністю $\pm 1,5$ мг. Під час вимірювань на одну шальку терезів розташовували рівноваги, а інша шалька терезів знаходилась у вільному підвішеному стані. Над поверхнею цієї шальки знаходилась площина п-подібної підставки, на яку розташовували тримач пробірок із досліджуваною речовиною, виготовлений із тефлону у вигляді циліндра висотою 60 мм, в середині якого зроблено отвір для розташування пробірки. Під час вимірювання рівень напоїв у пробірці забезпечував повне занурення дюралюмінієвої гирі включно із точкою підвіски.

Кожному циклу вимірювань передувало визначення маси гирі в повітрі та визначення маси гирі, зануреної у дистильовану воду. Це зроблено для зменшення сумарної похибки вимірювань, зокрема іiі частини, на яку впливає навіть кімнатна температура, адже вимірювання проводились у різні дні 3 різною кімнатною температурою в інтервалі $18-30{ }^{\circ} \mathrm{C}$.

Густину десертних емульсійних крем-лікерів визначали за формулою: 


$$
\rho=\frac{m}{V}
$$

де $m$ - маса десертного емульсійного кремлікеру, г;

$V$ - об'єм десертного емульсійного кремлікеру, $\mathrm{cm}^{3}$.

Під час реалізації методу гідростатичного зважування необхідно було визначити масу гирі в повітрі (разом із підвісом) $-m_{n}$, у дистильованій воді $-m_{6}$, та у досліджуваному напої $-m_{x}$. При цьому об'єм гирі визначався за формулою:

$$
V_{2}=\frac{m_{n}-m_{в}}{\rho_{\text {вод }}}
$$

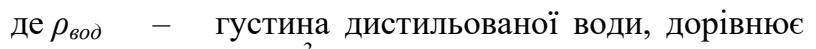
$1 \Gamma / \mathrm{cm}^{3}$

Знаючи об’єм, провели зважування гирі, зануреної в досліджувані лікери, і визначили $m_{x}$. Для визначення густини десертних емульсійних крем-лікерів ( $\left.\rho_{\text {лік }}\right)$ спочатку записали рівняння:

$$
m_{x}=m_{n}-\rho_{\text {лік }} \times V
$$

Звідки густина десертних емульсійних кремлікерів дорівнює:

$$
\rho_{\text {лік }}=\frac{m_{n}-m_{x}}{V}
$$

Дослідження змін густини десертних емульсійних крем-лікерів (моделювання можливих процесів розшарування під час їх струшування при приготуванні коктейлів) проводили на центрифузі типу ОПнЗУХЛ4.2 (Болгарія) зі швидкістю 1500 обертів за хвилину впродовж 18 хвилин. Контроль досліджуваних показників здійснювали на початку та через кожні три хвилини центрифугування.

Зразки поміщали у пробірки висотою 70 мм, які у верхній частині мали діаметр 25 мм. На довжині 50 мм пробірка має форму циліндра, потім має форму конуса, що звужується до діаметра 5 мм у нижній частині. Пробірки із зразками розташовували у спеціальні рухомі тримачі, які дають змогу займати пробіркам майже горизонтальне положення протягом центрифугування.

Результати та їх обговорення.Реологічні властивості харчових продуктів проявляються при їх деформації та характеризують здатність продуктів утворювати опір прикладеним ззовні силам або змінюватися під їх дією. Ці властивості залежать не лише від хімічного складу харчових продуктів, але й від їх будови та структури.

Однією $з$ важливих характеристик харчових продуктів є в'язкість - здатність середовища здійснювати опір прикладеним ззовні механічним зусиллям. В'язкість лікерів характеризує швидкість їх наливу. Динамічна в'язкість характеризує швидкість наливу напою в русі, кінематична - швидкість початку наливy.

Найбільше значення показника динамічної в'язкості визначено у зразка десертного емульсійного крем-лікеру “Цілюще джерело” (2394,1 мПа·с), а най- нижче - у “Здоров’ я” (2219,7 мПа•с), але всі вони є вищими, ніж динамічна в'язкість контрольного зразка, яка становить 1949,99 мПа·с (рис. 1).

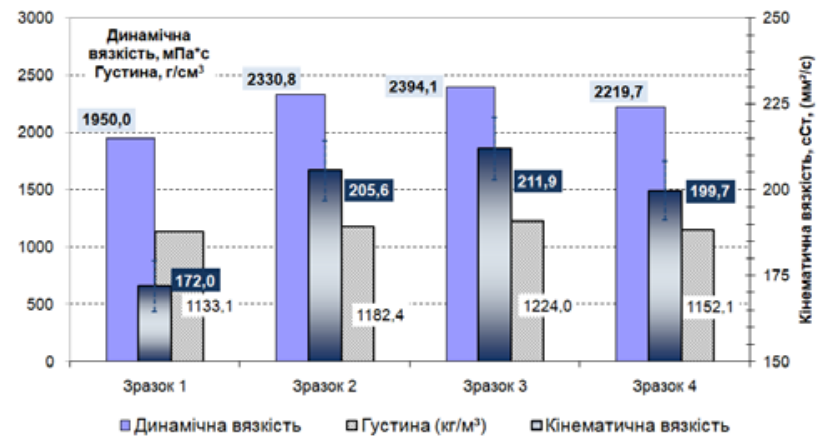

Рис. 1. Реологічні характеристики десертних емульсійних крем-лікерів за температури $20{ }^{\circ} \mathrm{C}$ (зразок 1 - "Dalkowski Advocaat Starotoruński"; зразок 2 - “Степова красуня” зразок 3 - “Цілюще джерело”; зразок 4 - “Здоров'я”)

Різниця в значеннях кінематичної в'язкості розроблених десертних емульсійних крем-лікерів також коливається в межах $20 \%$ порівняно із значенням кінематичної в'язкості контрольного лікеру $\left(172,0 \mathrm{~mm}^{2} / \mathrm{c}\right)$ i складає відповідно: для десертного емульсійного крем-лікеру "Степова красуня" $205,59 \mathrm{mм}^{2} / \mathrm{c}$; “Цілющого джерела" - 211,89 мм²/c; “Здоров'я" - 199,67 $\mathrm{Mм}^{2} / \mathrm{c}$.

Якщо значення кінематичної в'язкості розроблених напоїв перевищуватиме $20 \%$ порівняно із зазначеним показником контролю, лікери можуть здаватися занадто густими, висохлими, такими, що не є придатними для споживання.

Характеризуючи густину розроблених десертних емульсійних крем-лікерів, доцільно зазначити, що у крем-лікері “'Здоров'я” вона $\epsilon$ найнижчою і становить $1152,1 \mathrm{\kappa} / \mathrm{M}^{3}$ порівняно 3 густиною десертного емуль-

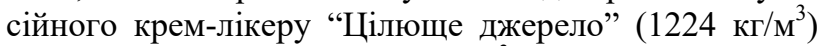

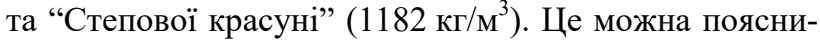
ти тим, що більш ефективними є комплексні природні емульгатори (білки та жири жовтка в комплексі 3 білками та вуглеводами цикорлакту), в той час як густина десертного емульсійного крем-лікеру “Здоров'я" обумовлена комплексом соєвого фітолецитину та цикорлакту.

Іншою важливою властивістю десертних емульсійних крем-лікерів $є$ поверхневий натяг - важлива термодинамічна характеристика поверхні розділу фаз, що являє собою роботу, яку слід виконати для створення одиниці площі нової поверхні. Її величина залежить від фізичних властивостей контактуючих фаз, наявності та походження домішок, температури, товщини перехідних зон між фазами тощо. Цей показник $\epsilon$ важливим, якщо розроблені лікери використовувати для приготування коктейлів (так само, як і придатний до цього контрольний зразок).

Дослідженнями встановлено, що найвищим поверхневим натягом характеризується десертний емульсійний крем-лікер “Цілюще джерело”, а найнижчим десертний емульсійний крем-лікер “Здоров’я” (рис. 2). Це пояснюється особливостями консистенції 
даних продуктів, яка, в свою чергу, залежить від сировинного складу розроблених десертних емульсійних крем-лікерів.

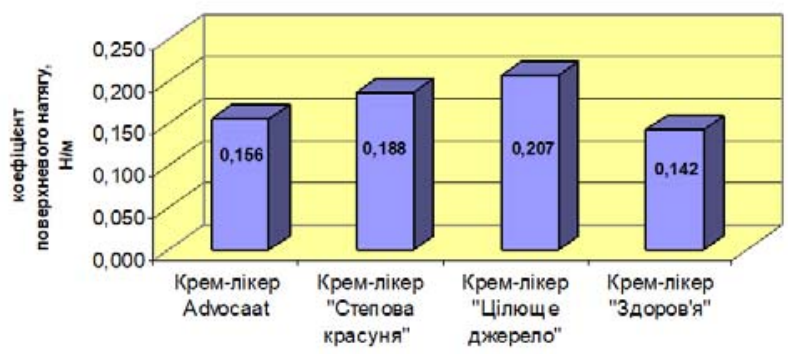

Рис. 2. Коефіцієнтповерхневого натягу десертних емульсійних крем-лікерів

Значення цього показника є важливим при споживанні десертних емульсійних крем-лікерів. Порівнюючи його із контрольним зразком, слід зазначити, що різниця тут також несуттєва. Таким чином, при наливі лікеру із скляної пляшки об'єм залишків рідини на її стінках будуть неістотно відрізнятися від об'єму залишків контрольного зразка. При приготуванні коктейлів (взаємодії лікеру 3 неіржавіючим корпусом шейкера) отримані дані засвідчили хорошу здатність до змішування розроблених нами продуктів.

Отримані результати досліджень дають підстави стверджувати, що найбільш доцільно для приготування коктейлів застосовувати десертний емульсійний крем-лікер “Цілюще джерело”.

Одним 3 чинників збереження якості харчових продуктів є додержання відповідних умов транспортування і зберігання. Готова продукція в результаті перевезення не повинна змінювати свої хімічні, фізичні та інші властивості, які можуть призвести до непридатності для реалізації. Оскільки розроблені нами десертні емульсійні крем-лікери є колоїдними системами, то їх важливими властивостями при перевезенні єреологічні.
Для моделювання перевезення 3 досліджуваними зразками було здійснено два типи механічних дій: центрифугування i струшування. Центрифугування гіпотетично може спричинити розшарування емульсії, а струшування - можливість повернення попередніх значень густини.

В той же час, при моделюванні процесів розшарування емульсії розроблених нами десертних емульсійних крем-лікерів під час їх зберігання або транспортування нами було помічено вплив часу зберігання напоїв на густину рідини.

Тому було поставлено завдання дослідити, як буде змінюватись густина під час центрифугування напоїв, тим самим моделюючи можливі процеси розшарування під час їх транспортування та зберігання.

Інтервал обертання центрифуги обрано фіксований -3 хв. Це пов'язано 3 можливістю почергово видаляти 3 досліджуваного напою спочатку молекули 3 найбільшою масою (в складі яких понад 3000 атомів), які першими за рахунок дії відцентрової сили осідають на стінках. За наступні 3 хв видаляються молекули 3 меншою кількістю атомів і т.д. В незалежності від хімічного складу молекул відбувається їх послідовна сепарація по масі.

Аналогічний процес буде відбуватися і під час нерухомого зберігання напоїв, тобто їх послідовного розшарування по масі молекул. В першу чергу на дно судин опустяться найважчі молекули, а у верхній частині напою залишаться найлегші.

Окрім цього нами було відмічено, що на густину десертних емульсійних крем-лікерів впливає їх струшування. Тому, після кожних 3 хв центрифугування спочатку вимірювали густину досліджуваного зразка, потім закрита пробірка переводилась в горизонтальне положення і струшувалась 200 разів з амплітудою в 40 см. Після цього знову вимірювали густину.

Залежність густини десертного емульсійного крем-лікеру “Здоров'я” від часу центрифугування за швидкості 1500 об./хв.наведено на рис. 3.

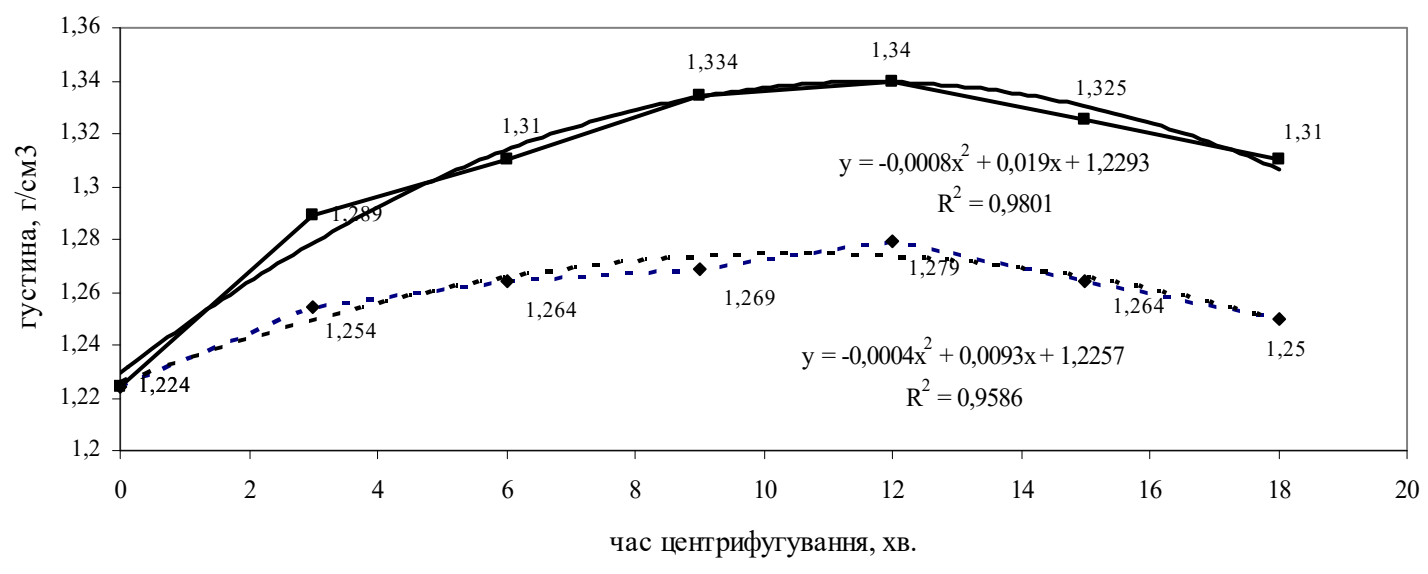

- $\rightarrow$ - - центрифугування $\longrightarrow$ - центрифугування + струшування

Рис. 3. Динаміка густини десертного емульсійного крем-лікеру “Здоров’я” під час центрифугування за швидкості 1500 об./хв

Як видно 3 рис. 3, при швидкості обертання центрифуги 1500 об./хв густина збільшується. Най- більш значною $є$ зміна після перших трьох хвилин обертання та наступного струшування дослідного 


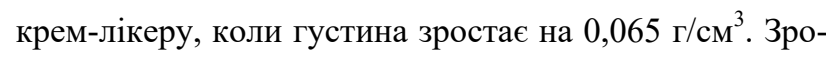
зуміло, що після центрифугування збільшення густини під час струшування може бути лише за рахунок молекул великої маси, які частково повертаються в рідину зі стінок пробірки. Повертаються в рідину далеко не всі молекули, оскільки після завершення вимірювань на дні пробірок залишався спресований осад жовто-білого кольору, який неможливо було видалити потоком води, і він видалявся лише механічно.

Слід відмітити, що в діапазоні з 12 до 15 хв змінюється хід кривих, що може свідчити про принципові зміни в структурі напою.

Аналогічні залежності спостерігалися і для десертного емульсійного крем-лікеру “Степова красуня” i десертного емульсійного крем-лікеру “Цілюще джерело" (рис. 4 та 5).

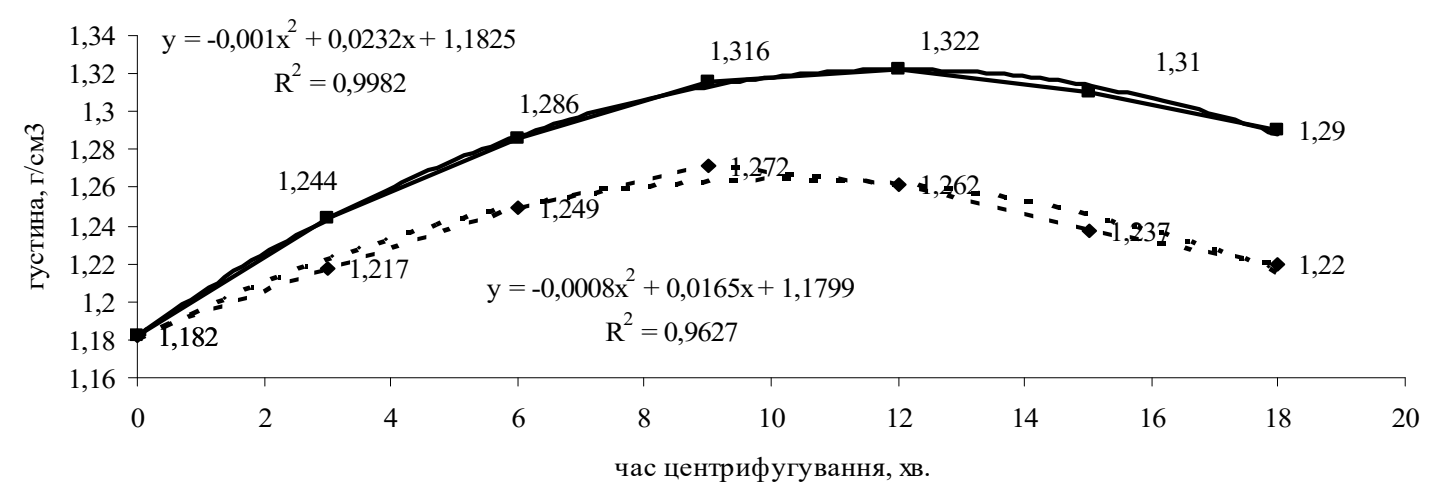

- -๑- - центрифругування —— центрифугування + струшування

Рис. 4. Динаміка густини десертного емульсійного крем-лікеру “Степова красуня” під час центрифугування за швидкості 1500 об./хв

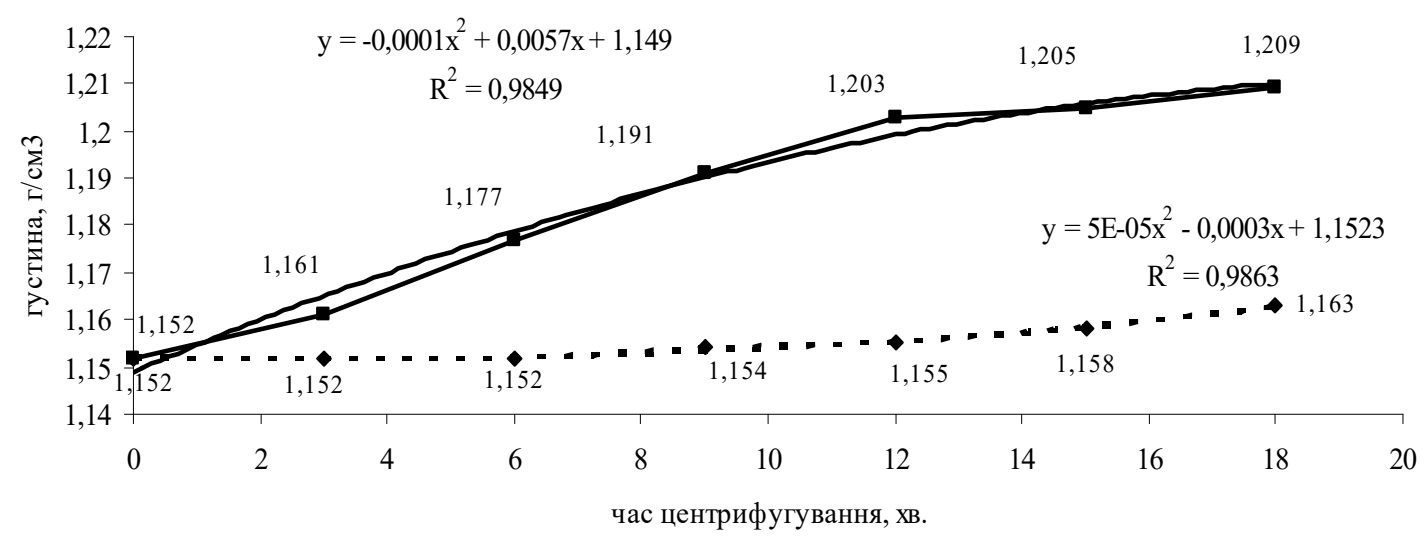

- -॰- - центрифугування ——- центрифугування + струшування

Рис. 5. Динаміка густини десертного емульсійного крем-лікеру “Цілюще джерело” під час центрифугування на швидкості 1500 об./хв

На відміну від десертних емульсійних крем-лікерів “Здоров'я" та "Степова красуня" амплітуда зміни густини десертного емульсійного крем-лікеру “Цілюще джерело” менша, що зумовлено його іншим рецептурним складом.

В той же час, доцільно зазначити, що густина десертних емульсійних крем-лікерів “Здоров'я” та “Степова красуня” після 15 хв дослідів починала стабілізуватися і повертатися до свого початкового значення.

Загалом, для всіх розроблених десертних емульсійних крем-лікерів спостерігались зміни ходу кривих в діапазоні часу центрифугування 6-9 хв.
Для деталізації вивчення впливу “ефекту струшування" на густину десертних емульсійних кремлікерів було побудовано графік залежності різниці їх густини до та після струшування від часу центрифугування при швидкості 1500 об./хв (рис. 6).

Найбільша різниця густини після струшування до 10 c - у крем-лікеру “Здоровя”, після 10с струшування - у крем-лікеру “Степова красуня". Найбільш стабільною виявилася структура колоїдної системи крем-лікеру “Цілюще джерело”. 


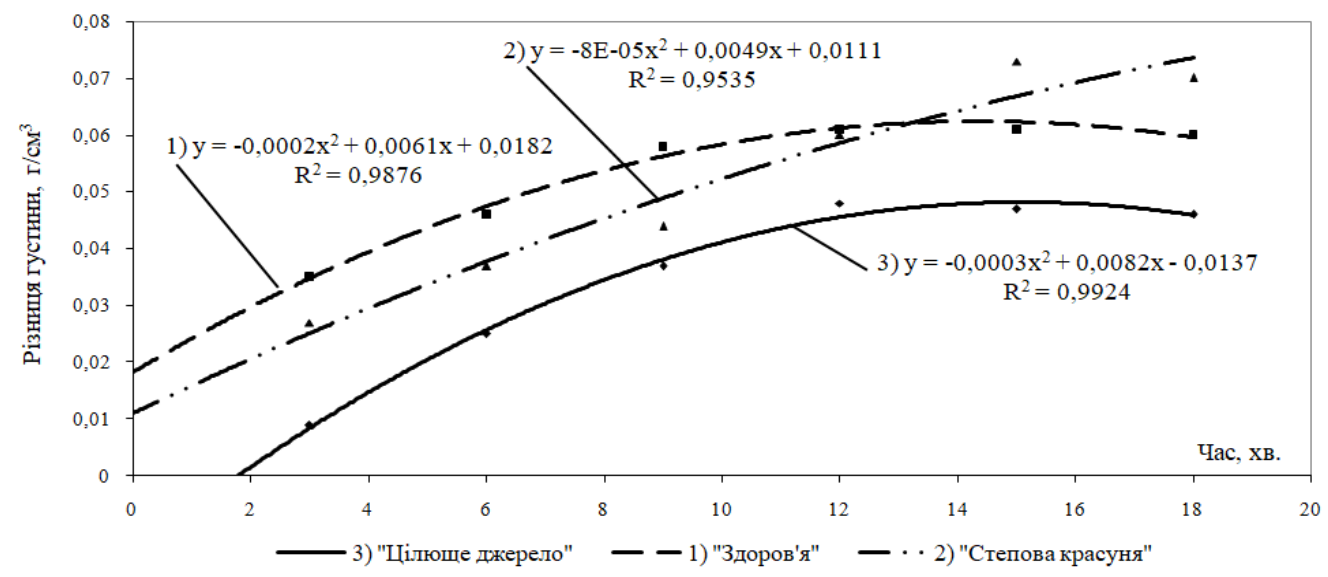

Рис. 6. Залежність різниці густин до та після струшування десертних емульсійних крем-лікерів від часу центрифугування

\section{Висновки}

Таким чином, за результатами проведених досліджень, можна стверджувати, що всі розроблені нами десертні емульсійні крем-лікери демонструють зміну густини як в процесі центрифугування, так і в процесі струшування;найменші зміни густини отримані нами для десертного емульсійного крем-лікеру “Цілющого джерела”, найбільші - для “Здоров'я”, що пов'язано 3 особливостями їх рецептурного складу. Доведено, що на початкових етапах зберігання і транспортування може відбуватися зміна консистенції (густини) розроблених напоїв $з$ наступною стабілізацією.

На підставі результатів моделювання процесів розшарування консистенції можна стверджувати, що десертні емульсійні крем-лікери “Здоров'я” і “Степова красуня" доцільно транспортувати з обережністю. “Цілюще джерело" може транспортуватися за будьяких умов та не вимагає збовтування під час зберігання, що обумовлено його рецептурою.

\section{References}

Ansell, G.C., \& Dickinson, E. (1985). Aggregate structure and coagulation kinetics in a concentrated dispersion of interacting colloidal particles. Chemical Physics Letters, 122(6), 594-598. doi: 10.1016/00092614(85)87277-8.

Antiushko, D., Motuzka, Yu., \& Romanenko, R. (2013). Reolohichni vlastyvosti produktiv dlia enteralnoho kharchuvannia. Tovary i rynky, 1, 125-130 (in Ukrainian).

Buffle, J., \& Leppard, G.G. (1995). Characterization of Aquatic Colloids and Macromolecules. Key Role of Physical Structures on Analytical Results. Environmental Science \& Technology, 29(9), 21762184. doi: 10.1021/es00009a005.

Cobley, A.G. (1994). Liquor and Leadership: Temperance, Drunkenness and the African Petty Bourgeoisie in South Africa. South African Historical Journal, 31(1), 128-148. doi: 10.1080/02582479408671800.

Djurkan, Je. (2002). Spirty i likery: per. s angl. M.: FAIRPRESS (in Russian).
DSTU HOST 10117.1-2003. Pliashky skliani dlia kharchovykh ridyn. Zahalni tekhnichni umovy (HOST 10117.1-2001, IDT). Vpershe iz skasuvanniam HOST 10117-91 v chastyni rozdiliv 2-5, HOST 26586-85 v chastyni rozdiliv 2-5 (in Ukrainian).

Hahn, R.A., Middleton, J.C., Elder, R., Brewer, R., Fielding, J. et al. (2012). Effects of alcohol retail privatization on excessive alcohol consumption and related harms: a community guide systematic review. American Journal of Preventive Medicine, 42(4), 418427. doi: 10.1016/j.amepre.2012.01.002.

Holub, B. (2006). Formuvannia spozhyvnoi tsinnosti novykh vydiv profilaktychnykh sukhykh sumishei dlia kavovykh napoiv. Tovary i rynky, 2, 123-125 (in Ukrainian).

Hrebelnyk, O.P., Kalinina, H.P., Pukhliak, A.H., \& Starovoitova, A.A. (2016). Zmina vlastyvostei sukhykh molochnykh produktiv za vidnovlennia. Naukovyi visnyk Lvivskoho natsionalnoho universytetu veterynarnoi medytsyny ta biotekhnolohii imeni Z.S. Hzhytskoho, 18, 1(65), 59-64. https://nvlvet.com.ua/index.php/food/article/view/322 2 (in Ukrainian).

Israelachvili, J., \& Wennerström, H. (1996). Role of hydration and water structure in biological and colloidal interactions. Nature, 379, 219-225. doi: 10.1038/379219a0.

Jarvis, P., Jefferson, B., \& Parsons, S.A. (2005). How the Natural Organic Matter to Coagulant Ratio Impacts on Floc Structural Properties. Environmental Science \& Technology, 39(22), 8919-8924. doi: 10.1021/es0510616.

Lovchev, V.M. (2013). Alkogol' v evropejskoj kul'ture: monografija. M.: ID KDU (in Russian).

Lynch, A.G., \& Milvihill, D.M. (1997). Effect of sodium caseinate on the stability of cream liqueurs International. Journal of Dairy Technology, 50(1), 17. doi: 10.1111/j.1471-0307.1997.tb01727.x.

Marynchenko, V.O., Domaretskyi, V.A., Shyian, P.L., Shvets, V.M., Tsyhankov, P.S., \& Zholner, I.D. (2003). Tekhnolohiia spyrtu. K.: Nats. un-t kharch. tekhnolohii (in Ukrainian).

Philipse, A.P., \& Wierenga, A.M. (1998). On the Density and Structure Formation in Gels and Clusters of 
Colloidal Rods and Fibers. Langmuir, 14(1), 49-54. doi: $10.1021 / 1$ a9703757.

Porokhniak-Hanovska, L. Rudniev, M., Kysla, L., Popova, V., Liashenko, V. (2002). Balzamy profilaktychnoi dii. Kharchova ta pererobna promyslovist, 12, 23 (in Ukrainian).

Rahimova, M.F., Levin, B.D., \& Krymkova, V.G. (2014). Razrabotka receptur likerov na baze rastitel'nogo syr'ja Sibiri. http://www.kgau.ru/new/all/konferenc/ konferenc/2014/f7.pdf (in Ukrainian).

Reglament (ES) № 1333/2008 Evropejskogo parlamenta i Soveta ES ot 16 dekabrja 2008 goda po pishhevym dobavkam. http://www.icqc.eu/userfiles/File/13332008-EC.pdf (in Russian).

Rehlament Yevropeiskoho parlamentu i rady (IeS) № 110/2008 vid 15 sichnia 2008 roku. Pro vyznachennia, opys, predstavlennia, markuvannia ta okhoronu heohrafichnykh zaznachen spyrtnykh napoiv ta skasuvannia Rehlamentu Rady (IeES) № 1576/89. http://zakon4.rada.gov.ua/laws/show/994_b12 (in Ukrainian).

Rudavska, H.B., \& Holub, B.O. (1999). Ozdorovchi produkty KhKhI storichchia. Visnyk KDTEU, 4, 4250 (in Ukrainian).

Savchuk, Y.Y., Usatiuk, S.I., \& Yanchyk, O.P. (2016). Dispersion research of drink from walnut. Scientific Messenger LNUVMBT named after S.Z. Gzhytskyj, 18, 2(68), 83-86. doi: 10.15421/nvlvet6816.

Shapoval, S.L., Romanenko, R.P., \& Forostiana, N.P. (2017). Diahnostyka fizychnykh vlastyvostei kharchovykh produktiv :monohrafiia.Kyiv: Kyiv. nats. torh.-ekon. un-t (in Ukrainian). 